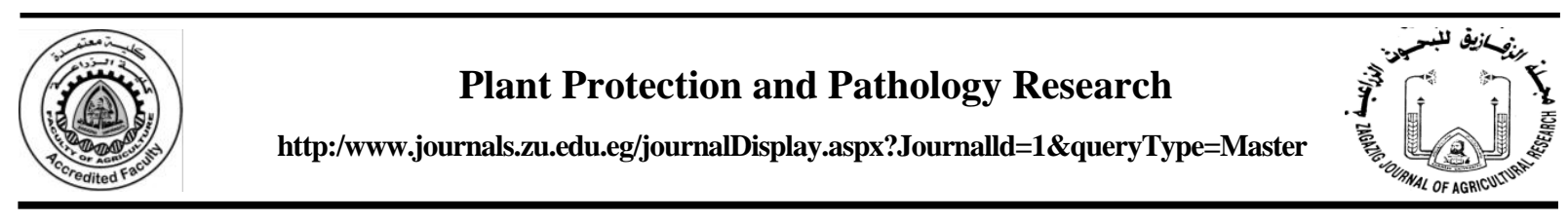

\title{
EFFICACY OF SOME INSECTICIDES, ADJUVANTS AND THEIR MIXTURES FOR CONTROLLING THE WHEAT APHID, Schizaphis graminum Rondani (Hemiptera: Aphididae) AND ONION THRIPS, Thrips tabaci ON WHEAT PLANTS
}

\author{
Hanaa M.G.E. Elalfy ${ }^{*}$, A.A.A. Aioub, A.A.M. Shalaby and A.E.A.M. El-Sobki \\ Plant Prot. Dept., Fac. Agric., Zagazig Univ., Egypt
}

\section{Received: 23/06/2019 ; Accepted: 02/09/2019}

\begin{abstract}
Field experiments were conducted to evaluate the effect of three insecticides individually and in combination with two adjuvants (Tween 80 and Sylgard 309) for control of the wheat aphid, Schizaphis graminum and onion thrips, Thrips tabaci on wheat plants during two successive growing seasons 2016 and 2017. The three tested insecticides were lambda- cyhalothrin 5\% $\mathrm{EC}$ at the rate of $100 \mathrm{ml} / 100 \mathrm{l}$, thiamethoxam $25 \% \mathrm{WG}$ at the rate of $20 \mathrm{~g} / 100 \mathrm{l}$ and malathion $57 \%$ $\mathrm{EC}$ at the rate of $150 \mathrm{ml} / 100 \mathrm{l}$. Twelve treatments (11 insecticides and their mixtures with adjuvants + control) were replicated four times in a completely randomized design. Chemicals were sprayed using a knapsack sprayer motor in separated plots (1/100 faddan). Mean numbers of wheat aphids and onion thrips were recorded before spraying and post treatment periods of 1, 3, 7 and 10 days. Results showed that application of the tested insecticide lambda-cyhalothrin either individually or in combination with sylgard 309 or tween 80 resulted in a significant reduction in the number of the wheat aphid recording $100 \%$ mortality in all treatments as initial effect in both seasons 2016 and 2017. Based on general average, a clear effects of lambda-cyhalothrin with sylgard 309, lambda- cyhalothrin with tween 80 and lambda- cyhalothrin were the highly toxic and rapidly kill the tested aphid recording $96.73,95.83$ and $95.43 \%$ mortality, respectively, in season 2016 and $98.33,98.12$ and $97.35 \%$ mortality, respectively, in season 2017 followed by thiamethoxam and its mixtures then malathion with sylgard 309 , malathion with tween 80 and malathion alone recording $86.30,85.87$ and $83.56 \%$ mortality, respectively, in season 2016 and 90.77, 90.63 and 88.60\% mortality, respectively, in season 2017 . After 1 day of spray, lambda-cyhalothrin recorded the most effective treatment resulting in $100 \%$ thrips reduction, the same result was recorded for lambda-cyhalothrin + sylgard $309(100 \%)$ and lambda-cyhalothrin + tween $80(100 \%)$. Thiamethoxam, malathion and their mixtures with the two adjuvants caused also $100 \%$ thrips reduction. Mortality percentage induced by sylgard 309 and tween 80 were only 56.67 and $49.58 \%$, respectively during season 2016. Similar results were recorded after $24 \mathrm{hr}$. of application in the second season 2017. After 3, 7 and 10 days of treatments, lambdacyhalothrin plus sylgard 309, lambda-cyhalothrin + tween 80 and lambda-cyhalothrin alone induced the highest percentages of mortality during seasons 2016 and 2017, respectively, which differed significantly than control. Moreover thiamethoxam with sylgard 309 was recorded 100, 92.77 and $87.40 \%$ thrips reduction after 3, 7 and 10 days from spray, respectively, during seasons 2017. However, the results showed also that malathion and its mixtures caused lower percent mortality than the other two tested insecticides and its mixtures during season 2016 and 2017. All the insecticides and their mixtures were significantly better than untreated check in reducing the tested pests population. Lambda- cyhalothrin proved the best effect followed by thiamethoxam and malathion.
\end{abstract}

Key words: Insecticides, adjuvants, lambda-cyhalothrin, thiamethoxam, malathion, aphid, thrips.

\footnotetext{
*Corresponding author: Tel. : +201227951943

E-mail address: hanaaelalfy465@gmail.com
} 


\section{INTRODUCTION}

Wheat (Triticum aestivum L.)plays an important role in the diet of Egyptians, while the annual production of wheat is insufficient to cover Egyptian demand (El-Hariry, 1979; ElHeneidy, 1994). Wheat crop is attacked by several insect pests such as army worm, cut worm (Noctuidae: Lepidoptera), termites (termitidae: isoptera), wheat beetles and weevils (Chrysomelidae, Carabidae, Curculionidae: Coleoptera) thrips (Thripidae: Thysanoptera) and Aphids (Aphididae: Homoptera) (Naeem et al., 2016). Wheat aphids are considered one of the most destructive insects of wheat plants (Dewar and Carter, 1984; Steffey, 2012). Direct damage that aphids cause to crops include: sap ingestion, desiccation of leaves, reduced germination potential and productivity, and finally plant death. Indirect damage is caused through stunting and premature plant death, reduction in photosynthesis, as well as sterilization of inflorescences, plentiful honeydew production, which may result in deformed leaves, and growth of sooty mold (Blackman and Eastop, 2000). Aphids may reduce wheat production by causing 35-40\% yield losses directly through sucking injury and $20-80 \%$ yield losses indirectly by transmitting viral and fungal diseases (Kieckhefer and Gellner, 1992; Girma et al., 1993; Trdan and Milevoj, 1999). Thrips cause evident damage to winter wheat, whose development most closely overlaps with the life cycle of thrips. (Parrella and Lewis, 1997; Mound, 2005; Moritz, 2006). Both adults and larvae impact winter wheat development, the latter being more destructive by affecting partial or complete white ear effect, drying of flag leaf, partial ear fertilization, and incomplete grain filling (Volkmar et al., 2009; Gaafar, 2010). Thrips are tiny insects that reproduce rapidly, congregate in tight places that make pesticide coverage difficult, and feed with rasping-piercing-sucking mouth parts, resulting in deformation of leaves (Duraimurugan and Jagadish, 2011).

Various environment friendly control measures are available to keep the aphids below economic injury level (EIL). These control measures included cultural, biological, chemical and host plant resistance (Hatchett et al., 1987).
Host plant resistance is more important, which can keep aphid populations below the economic threshold level and reduce the chance of biotypes development. Combination of non-chemical i.e. host plant resistance and natural enemies can keep aphids population below economic injury level. But in case of aphid's population build up selective insecticide should be applied to control aphids outbreak on wheat and decrease the chance of economic losses (Newsom, 1980; Lowe, 1987). The aim of this study was to evaluate the efficacy of insecticides lambdacyhalothrin, thiamethoxam and malathion against aphids and thrips attacking wheat plants

\section{MATERIALS AND METHODS}

\section{Insecticides and Adjuvants Used}

Tested pesticides trade names, formulation types, percentage of active ingredients, Chemical formula and application rate are presented in Table 1. The pesticide concentrations used in this study were based on the labeled recommendation rate. Tested adjuvants were sylgard 309 used at the rate of $1 \%$ and tween 40 used at the rate of $0.25 \%$.

\section{Experiment Design}

This experiment was conducted in wheat field (Egyptian cultivar Misr-1) at Zagazig District, Sharkia Governorate, Egypt, during 2016 and 2017 seasons. The experimental area was divided into plots of $10 \times 10$ meters each. Tested insecticides were distributed in a complete randomized block design (CRBD) in four replicates for each treatment and untreated control. A knapsack sprayer with one nozzle beam was used in application of insecticide solution at the rate of 200 liters per faddan. Insecticides were applied on March $16^{\text {th }}, 2016$ and on April 7 ${ }^{\text {th }}, 2017$ growing seasons. Samples of twenty five wheat plants (after 14 weeks from planting) were randomly selected from each replicate immediately before insecticides application and after treatment at the intervals of $1,3,7$ and 15 days post-treatment for evaluating the initial and the residual activity of these insecticides on aphid and thrips populations. In field, aphid and thrips population were recorded in the early morning hours from terminal branches, leaves, stems and spikes in 25 plants for each replicate before and after treatment periods. 
Zagazig J. Agric. Res., Vol. 46 No. (6A) 2019

Table 1 . Descriptions of the tested insecticides used

\begin{tabular}{lcccc}
\hline Common name & Trade name & $\begin{array}{c}\text { (a.i.)\% and } \\
\text { formulation }\end{array}$ & $\begin{array}{c}\text { Chemical } \\
\text { formula }\end{array}$ & $\begin{array}{c}\text { Recommended } \\
\text { rate }\end{array}$ \\
\hline Lambda-cyhalothrin & Lambada & $5 \% \mathrm{EC}$ & $\mathrm{C}_{23} \mathrm{H}_{19} \mathrm{ClF}_{3} \mathrm{NO}_{3}$ & $100 \mathrm{ml} / 100 \mathrm{l}$ \\
Thiamethoxam & Actara & $25 \% \mathrm{WG}$ & $\mathrm{C}_{8} \mathrm{H}_{10} \mathrm{ClN}_{5} \mathrm{O}_{3} \mathrm{~S}$ & $20 \mathrm{~g} / 1001$ \\
Malathion & Malason/cheminova & $57 \% \mathrm{EC}$ & $\mathrm{C}_{10} \mathrm{H}_{19} \mathrm{O}_{6} \mathrm{PS}_{2}$ & $150 \mathrm{ml} / 1001$ \\
\hline
\end{tabular}

The percentages of aphid and thrips reduction were calculated according to Henderson and Tilton's equation (1955) as follow:

Reduction $(\%)=100 \times 1-(\mathrm{Ta} \times \mathrm{Cb}) / \mathrm{Tb} \times \mathrm{Ca})$

Where:

$\mathrm{C}=$ Insect number in the untreated control plot.

$\mathrm{T}=$ Insect number in the treated plot.

$\mathrm{a}=$ After insecticide application.

$\mathrm{b}=$ Before insecticide application.

\section{Statistical Analysis}

All data were statistically analyzed using the general linear models procedure of the statistical analysis system SPSS (22). Significances of differences were defined at $\mathrm{p}<0.05$. All experiments as well as related analysis results were repeated three times and all obtained data are expressed as averages.

\section{RESULTS AND DISCUSSIONS}

Efficiency of the Tested Chemicals and Their Binary Mixtures Against the Wheat Aphid, Schizaphis graminum

Efficacy of the tested insecticides, two adjuvants and their combinations against the wheat aphid on wheat plant under field conditions were presented in Tables 2 and 3. Application of the tested insecticide lambdacyhalothrin either alone or in combination with sylgard 309 and tween 80 resulted in a significant reduction in the number of the wheat aphid recording $100 \%$ mortality for all treatments as initial effect in both seasons (2016 and 2017). Thiamethoxan and its mixtures with both adjuvants came in the second position followed by malathion and their mixtures which recorded the least efficacy. Sylgard 309 and tween 80 significantly decreased the number of $S$. graminum as an initial effect in both seasons recording 39.68 and $38 \%$ mortality in season 2016 (Table 2) and 39.30 and $38.75 \%$ mortality in season 2017 (Table 3), respectively. Based on general average, a clear deleterious effects of lambda- cyhalothrin with sylgard 309, lambdacyhalothrin with tween 80 and followed by lambda- cyhalothrin were the highly toxic and rapidly kill the tested aphid recording 96.73, 95.83 as well as $95.43 \%$ mortality, respectively, in season 2016 and 98.33, 98.12 and $97.35 \%$ mortality, respectively, in season 2017 followed by thiamethoxam and its mixtures then malathion with sylgard 309, malathion with tween 80 followed by malathion alone recording $86.3,85.87$ and $83.56 \%$ mortality, respectively, in season 2016 as well as 90.77, 90.63 and $88.60 \%$ mortality, respectively in season 2017. All treatments were significantly differed compared with the control (untreated). Contrarily, adjuvants had a less toxic effect as initial and general average. Indeed, during a 2016-2017 the insecticides and their combinations with adjuvants versus the control had a significant effect on the number of aphid. The results clearly indicated that adjuvants increased the efficiency of the tested insecticides against wheat aphid in wheat field in both seasons. These results are in harmony with those obtained by Abd-Ella (2015) who indicated that neonicotinoids (acetamiprid, imidacloprid, thiamethoxam and dinotefuran), organophosphate (malathion) and carbamate (pirimicarb) insecticides significantly reduced the pomegranate aphid, Aphis punicae population by an average of 70.6 - $90.7 \%$. The greatest control of A. punicae was achieved by thiamethoxam > acetamiprid > imidacloprid > pirimicarb > dinotefuran > malathion. Thiamethoxam, dinotefuran, acetamiprid 
Elalfy, et al.

Table 2. Efficiency of the insecticides, adjuvants and their mixtures against the wheat aphid, Shizaphis graminum (2016 season)

\begin{tabular}{|c|c|c|c|c|c|c|c|}
\hline \multirow[t]{2}{*}{ Treatment } & \multirow[t]{2}{*}{$\begin{array}{c}\text { Count } \\
\text { before } \\
\text { spraying }\end{array}$} & \multirow[t]{2}{*}{$\begin{array}{l}\text { Initial } \\
\text { effect }\end{array}$} & \multicolumn{3}{|c|}{$\begin{array}{l}\text { Number of individuals and } \\
\text { reduction percentage after } \\
\text { different days post - treatment }\end{array}$} & \multirow[t]{2}{*}{$\begin{array}{l}\text { Mean of } \\
\text { residual } \\
\text { effect }\end{array}$} & \multirow[t]{2}{*}{$\begin{array}{l}\text { General } \\
\text { average }\end{array}$} \\
\hline & & & 3 & 7 & $\mathbf{1 0}$ & & \\
\hline \multirow[t]{2}{*}{ Lambda-cyhalothrin } & $38.25^{\mathrm{ijkl}}$ & $0.00^{\mathrm{b}}$ & $2^{\text {yzab }}$ & $5^{\text {tuvwxy }}$ & $8.5^{\mathrm{s}}$ & 5.17 & 3.88 \\
\hline & Red. \% & 100 & 96.31 & 94.4 & 91 & 93.90 & 95.43 \\
\hline \multirow[t]{2}{*}{ Malathion } & $35.25^{\operatorname{lm}}$ & $2.5^{\mathrm{xyzab}}$ & $6.25^{\text {stuvw }}$ & $15.75^{\mathrm{q}}$ & $24.25^{\mathrm{op}}$ & 15.42 & 12.19 \\
\hline & Red. \% & 93.5 & 87.47 & 80.89 & 72.4 & 80.25 & 83.57 \\
\hline \multirow[t]{2}{*}{ Thiamethoxam } & $34.75^{\mathrm{m}}$ & $1.5^{\mathrm{ab}}$ & $3.5^{\mathrm{wxyza}}$ & $8^{\text {st }}$ & $13.25^{\mathrm{qr}}$ & 8.25 & 6.56 \\
\hline & Red. \% & 96 & 92.88 & 90.15 & 84.70 & 89.24 & 90.93 \\
\hline \multirow[t]{2}{*}{ Sylgard 309} & $40.25^{\mathrm{hi}}$ & $26.5^{\circ}$ & $35.5^{\mathrm{Im}}$ & $62^{\mathrm{e}}$ & $68.25^{\mathrm{d}}$ & 55.25 & 48 \\
\hline & Red.\% & 39.68 & 37.69 & 34.12 & 31.98 & 34.59 & 35.87 \\
\hline \multirow[t]{2}{*}{ Tween 80} & $44^{\mathrm{g}}$ & $29.75^{\mathrm{n}}$ & $39.25^{\mathrm{ij}}$ & $69^{d}$ & $76.25^{\mathrm{c}}$ & 61.5 & 53.56 \\
\hline & Red.\% & 38 & 36.98 & 32.93 & 30.49 & 33.47 & 34.6 \\
\hline \multirow[t]{2}{*}{ Lambda-cyhalothrin+sylgard 309} & $43^{\mathrm{gh}}$ & $0.00^{\mathrm{b}}$ & $1^{\mathrm{ab}}$ & $4.25^{\mathrm{vwxyza}}$ & $7.75^{\text {stu }}$ & 4.33 & 3.25 \\
\hline & Red.\% & 100 & 98.36 & 95.77 & 92.77 & 95.63 & 96.73 \\
\hline \multirow[t]{2}{*}{ Lambda-cyhalothrin+tween 80} & $36.75^{\mathrm{jklm}}$ & $0.00^{\mathrm{b}}$ & $1.25^{\mathrm{ab}}$ & $4.75^{\mathrm{uvwxyz}}$ & $8^{\text {stu }}$ & 4.67 & 3.5 \\
\hline & Red.\% & 100 & 97.59 & 94.47 & 91.27 & 94.44 & 95.83 \\
\hline \multirow[t]{2}{*}{ Malathion+sylgard 309} & $38.75^{\mathrm{ijk}}$ & $1.75^{\text {zab }}$ & $5.5^{\text {sturwx }}$ & $15^{\mathrm{qr}}$ & $23.25^{\mathrm{p}}$ & 14.58 & 11.38 \\
\hline & Red.\% & 95.86 & 89.97 & 83.44 & 75.93 & 83.11 & 86.3 \\
\hline \multirow[t]{2}{*}{ Malathion+tween 80} & $39.5^{\mathrm{ij}}$ & $2^{\text {yzab }}$ & $6^{\text {stuvw }}$ & $15.5^{\mathrm{qr}}$ & $24^{\text {op }}$ & 15.17 & 11.8 \\
\hline & Red.\% & 95.36 & 89.27 & 83.22 & 75.63 & 82.71 & 85.87 \\
\hline \multirow[t]{2}{*}{ Thiamethoxam +sylgard 309} & $39.5^{\mathrm{ij}}$ & $0.00^{\mathrm{b}}$ & $2.5^{\mathrm{xyzab}}$ & $6.75^{\text {stuv }}$ & $12.5^{\mathrm{r}}$ & 7.25 & 5.44 \\
\hline & Red.\% & 100 & 95.53 & 92.69 & 87.31 & 91.84 & 93.88 \\
\hline \multirow[t]{2}{*}{ Thiamethoxam +tween 80} & $37.75^{\mathrm{ijklm}}$ & $0.00^{\mathrm{b}}$ & $2.75^{\text {xyzab }}$ & $7.5^{\mathrm{stu}}$ & $13^{\mathrm{qr}}$ & 7.75 & 5.81 \\
\hline & Red.\% & 100 & 94.85 & 91.5 & 86.19 & 90.85 & 93.14 \\
\hline Control & $35.5^{\mathrm{klm}}$ & $38.75^{\mathrm{ijk}}$ & $50.25^{\mathrm{f}}$ & $83^{\mathrm{b}}$ & $88.5^{\mathrm{a}}$ & 73.92 & 65.13 \\
\hline
\end{tabular}

$\mathrm{LSD} \leq 0.05$ level for treatments $=1.1704$ LSD $\leq 0.05$ level for periods $=0.9474$

$\mathrm{LSD} \leq 0.05$ level for interactions between $(\mathrm{TxP})=3.1600$ 
Zagazig J. Agric. Res., Vol. 46 No. (6A) 2019

Table 3. Efficiency of the insecticides, adjuvants and their mixtures against the wheat aphid, Shizaphis graminum (2017 season)

\begin{tabular}{|c|c|c|c|c|c|c|c|}
\hline \multirow[t]{2}{*}{ Treatment } & \multirow[t]{2}{*}{$\begin{array}{c}\text { Count } \\
\text { before } \\
\text { spraying }\end{array}$} & \multirow[t]{2}{*}{$\begin{array}{c}\text { Initial } \\
\text { effect }\end{array}$} & \multicolumn{3}{|c|}{$\begin{array}{l}\text { Number of individuals and } \\
\text { reduction percentage after } \\
\text { different days post-treatment }\end{array}$} & \multirow[t]{2}{*}{$\begin{array}{c}\text { Mean of } \\
\text { residual } \\
\text { effect }\end{array}$} & \multirow[t]{2}{*}{$\begin{array}{l}\text { General } \\
\text { average }\end{array}$} \\
\hline & & & 3 & 7 & 10 & & \\
\hline \multirow[t]{2}{*}{ Lambda-cyhalothrin } & $28^{\mathrm{m}}$ & $0.00^{\mathrm{w}}$ & $0.00^{\mathrm{w}}$ & $2.5^{\text {stuvw }}$ & $4.5^{\mathrm{rstu}}$ & 2.33 & 1.75 \\
\hline & Red.\% & 100 & 100 & 96 & 93.38 & 96.46 & 97.35 \\
\hline \multirow[t]{2}{*}{ Malathion } & $30.75^{\mathrm{jklm}}$ & $1.5^{\mathrm{uvw}}$ & $4^{\text {rstuv }}$ & $9.25^{\mathrm{p}}$ & $13.75^{\circ}$ & 9 & 7.13 \\
\hline & Red.\% & 95.69 & 90.5 & 86.65 & 81.57 & 86.24 & 88.60 \\
\hline \multirow[t]{2}{*}{ Thiamethoxam } & $31.25^{\mathrm{ijkl}}$ & $0.00^{\mathrm{w}}$ & $2^{\mathrm{tuvw}}$ & $6^{\mathrm{qr}}$ & $10.75^{\text {op }}$ & 6.25 & 4.69 \\
\hline & Red.\% & 100 & 95.32 & 91.48 & 85.82 & 90.87 & 93.16 \\
\hline \multirow[t]{2}{*}{ Sylgard 309} & $33.5^{\text {ghij }}$ & $23^{\mathrm{n}}$ & $29.5^{\operatorname{lm}}$ & $51.25^{\mathrm{e}}$ & $56.75^{\mathrm{d}}$ & 45.83 & 40.13 \\
\hline & Red.\% & 39.30 & 35.67 & 32.13 & 30.18 & 32.66 & 34.32 \\
\hline \multirow[t]{2}{*}{ Tween 80} & $35^{\text {gh }}$ & $24.25^{\mathrm{n}}$ & $32.25^{\text {hijkl }}$ & $54.5^{\mathrm{d}}$ & $60.25^{\mathrm{c}}$ & 49 & 42.81 \\
\hline & Red.\% & 38.75 & 32.69 & 30.92 & 29 & 30.87 & 32.84 \\
\hline \multirow[t]{2}{*}{ Lambda-cyhalothrin+sylgard 309} & $30^{\mathrm{klm}}$ & $0.00^{\mathrm{w}}$ & $0.00^{\mathrm{w}}$ & $1.5^{\mathrm{uvw}}$ & $3.25^{\text {rstuv }}$ & 1.58 & 1.19 \\
\hline & Red.\% & 100 & 100 & 97.78 & 95.53 & 97.77 & 98.33 \\
\hline \multirow[t]{2}{*}{ Lambda-cyhalothrin+tween 80} & $32.25^{\text {hijkl }}$ & $0.00^{\mathrm{w}}$ & $0.00^{\mathrm{w}}$ & $2^{\text {tuvw }}$ & $3.75^{\text {rstuv }}$ & 1.92 & 1.44 \\
\hline & Red.\% & 100 & 100 & 97.25 & 95.21 & 97.49 & 98.12 \\
\hline \multirow[t]{2}{*}{ Malathion+sylgard 309} & $33^{\text {ghijk }}$ & $1^{\mathrm{vw}}$ & $3.25^{\text {rstuv }}$ & $8.5^{\mathrm{pq}}$ & $12.5^{\circ}$ & 8.08 & 6.31 \\
\hline & Red.\% & 97.32 & 92.80 & 88.57 & 84.39 & 88.59 & 90.77 \\
\hline \multirow[t]{2}{*}{ Malathion+tween 80} & $35.5^{\mathrm{g}}$ & $1.25^{\mathrm{vw}}$ & $3.75^{\text {rstuv }}$ & $9^{\mathrm{pq}}$ & $13.25^{\circ}$ & 8.67 & 6.81 \\
\hline & Red.\% & 96.89 & 92.28 & 88.75 & 84.62 & 88.55 & 90.64 \\
\hline \multirow[t]{2}{*}{ Thiamethoxam +sylgard 309} & $34.25^{\text {ghi }}$ & $0.00^{\mathrm{w}}$ & $1.25^{\mathrm{vw}}$ & $4.75^{\mathrm{rst}}$ & $8.5^{\mathrm{pq}}$ & 4.83 & 3.63 \\
\hline & Red.\% & 100 & 97.33 & 93.85 & 89.77 & 93.65 & 95.24 \\
\hline \multirow[t]{2}{*}{ Thiamethoxam +tween 80} & $32.5^{\text {ghijkl }}$ & $0.00^{\mathrm{w}}$ & $1.5^{\mathrm{uvw}}$ & $5.25^{\mathrm{rs}}$ & $9^{\text {pq }}$ & 5.25 & 3.94 \\
\hline & Red.\% & 100 & 96.63 & 92.83 & 88.59 & 92.68 & 94.51 \\
\hline Control & $30.5^{\mathrm{jklm}}$ & $34.5^{\mathrm{gh}}$ & $41.75^{\mathrm{f}}$ & $68.75^{\mathrm{b}}$ & $74^{\mathrm{a}}$ & 61.5 & 54.75 \\
\hline
\end{tabular}

LSD $\leq 0.05$ level for treatments $=1.6978$

LSD $\leq 0.05$ level for periods $=0.8892$

$\mathrm{LSD} \leq 0.05$ level for interactions between $(\mathrm{TxP})=3.2359$ 


\section{Elalfy, et al.}

and imidacloprid proved to be the most effective insecticides in reducing cotton aphid, A. gossypii population up to 21 days after treatment throughout both seasons of study and caused an average reduction percentage ranged from 73.58 to $96.42 \%$, whereas pirimicarb and malathion showed the lowest reduction (Gaber et al., 2015). Lambda cyhalothrin and imidacloprid, were effective in lowering aphid density in strawberry; however lambda cyhalothrin yielded better results as compared to imidacloprid. Aphid population significantly reduced after the spray of cyhalothrin and imidacloprid (Ul Ane et al., 2016).

\section{Efficiency of the Tested Chemicals and Their Binary Mixtures Against the Onion Thrips, Thrips tabaci}

Results concerning the efficacy of the three insecticides (lambda-cyhalothrin, malathion and thiamethoxam), the two adjuvants and their binary mixtures against the onion thrips are presented in Tables 4 and 5. The wheat plants were carefully inspected at weekly interval to monitor the thrips infestation. The tested chemicals were used when the insect counting were reached to a suitable numbers. The results showed that all the tested insecticides, two adjuvants and their binary mixtures were significantly better than the control. After 1 day of spray, lambda-cyhalothrin recorded the most effective treatment with a minimum mean thrips population per plant ( 0.00 individuals) resulting $100 \%$ thrips reduction, the same result was recorded for lambda-cyhalothrin + sylgard 309 $(100 \%)$ and lambda-cyhalothrin + tween 80 $(100 \%)$. Thiamethoxam, malathion and their mixtures with the two adjuvants caused also $100 \%$ thrips reduction. Mortality percentage induced by sylgard 309 and tween 80 were only 56.67 and $49.58 \%$, respectively, during season 2016. Similar results were recorded after $24 \mathrm{hr}$. of treatments in the second season 2017. After 3, 7 and 10 days of treatments, lambda-cyhalothrin plus sylgard 309, lambda-cyhalothrin + tween 80 and lambda-cyhalothrin alone induced the highest percentages of mortality during seasons 2016 and 2017, respectively, which differed significantly than control. Moreover thiamethoxam with sylgard 309 was recorded 100, 92.77 and $87.40 \%$ thrips reduction after 3,7 and 10 days from spray, respectively, during seasons 2017. However, the results showed also that malathion and its mixtures caused lower percent mortality than the other two tested insecticides and its mixtures during seasons 2016 and 2017. Lambdacyhalothrin and its mixtures appeared to be the most persistent treatment, followed by thiamethoxam and its mixtures meanwhile, malathion and its mixtures with adjuvants recorded the lowest efficiency against the wheat thrips. These results are in harmony with Sadozai et al. (2009) who studied the efficacy of different insecticides against onion thrips in Taharan- Peshawar. All the tested insecticides were significantly more effective than the untreated check in reducing pest population after both applications. Thiodan proved the best followed by curacron and karate. El-Naggar and Zidan (2013) evaluated the effectiveness of imidacloprid and thiamethoxam, used separately as seed treatments and foliar applications at the recommended rate against the sucking insects: thrips, T. tabaci (lind), jassid, Empoasca spp., whitefly, Bemicia tabaci, and cotton aphid, $A$. gossypii (Glover.). Results showed the following trends: Seed treatment with imidacloprid and thiamethoxam protected cotton seedlings from thrips for at least 6 weeks from the onset of seed planting. Imidacloprid had a better efficiency against this sap. The results also revealed that imidacloprid had more adverse effects on soil fauna than thiamethoxam.sucking pest than thiamethoxam. Treatments with imidacloprid and thiamethoxam as foliar applications were highly effective against aphids. Bereś et al. (2016) tested two insecticides: Karate Zeon 050 CS, containing lambda-cyhalothrin, and Proteus 110 OD, containing thiacloprid with deltamethrin on thrips abundance on maize. The tested active substances showed high effectiveness against thrips, but a better effect reflected in a decrease in thrips abundance was found for the mixture of thiacloprid with deltamethrin. The tested insecticides significantly reduced the population of thrips for up to 14 days after treatment. Ding et al. (2018) determined the control efficacy of seven neonicotinoid insecticides of seed treatments against corn thrips. The results showed that, among the tested neonicotinoid seed treatments each of thiamethoxam (1.0 and $2.0 \mathrm{~g}$ active ingredient (AI) $/ \mathrm{kg}$ of seeds), clothianidin (1.0 and $2.0 \mathrm{~g}$ $\mathrm{AI} / \mathrm{kg}$ of seeds), and imidacloprid (2.0 $\mathrm{g} \mathrm{AI} / \mathrm{kg}$ of seeds) was the highest in control efficacy against corn thrips throughout the corn growing season. Treating corn seeds with thiamethoxam, clothianidin, and imidacloprid can provide effective protection against early-season thrips and reduce yield losses under field conditions. 
Zagazig J. Agric. Res., Vol. 46 No. (6A) 2019

Table 4. Efficiency of the tested insecticides,two adjuvants and their mixtures against the onion thrips, Thrips tabaci attacking wheat plants in the field during 2016 season

\begin{tabular}{|c|c|c|c|c|c|c|c|}
\hline \multirow[t]{2}{*}{ Treatment } & \multirow[t]{2}{*}{$\begin{array}{l}\text { Count } \\
\text { before } \\
\text { spraying }\end{array}$} & \multirow[t]{2}{*}{$\begin{array}{c}\text { Initial } \\
\text { effect }\end{array}$} & \multicolumn{3}{|c|}{$\begin{array}{l}\text { Number of individuals and } \\
\text { reduction percentage after } \\
\text { different days from application }\end{array}$} & \multirow[t]{2}{*}{$\begin{array}{l}\text { Mean of } \\
\text { residual } \\
\text { effect }\end{array}$} & \multirow[t]{2}{*}{$\begin{array}{l}\text { General } \\
\text { average }\end{array}$} \\
\hline & & & 3 & 7 & 10 & & \\
\hline \multirow[t]{2}{*}{ Lambda-cyhalothrin } & $14.25^{\mathrm{abcd}}$ & $0.00^{\mathrm{m}}$ & $0.00^{\mathrm{m}}$ & $1.75^{\mathrm{klm}}$ & $2.75^{\mathrm{jklm}}$ & 1.5 & 1.13 \\
\hline & Red. $\%$ & 100 & 100 & 91.57 & 86.95 & 92.84 & 94.63 \\
\hline \multirow[t]{2}{*}{ Malathion } & $14.5^{\mathrm{abcd}}$ & $0.00^{\mathrm{m}}$ & $1.5^{\mathrm{lm}}$ & $5.25^{\text {hijkl }}$ & $6.5^{\text {ghij }}$ & 4.42 & 3.31 \\
\hline & Red.\% & 100 & 91.19 & 75.14 & 69.68 & 78.67 & 84 \\
\hline \multirow[t]{2}{*}{ Thiamethoxam } & $12^{\text {bcde }}$ & $0.00^{\mathrm{m}}$ & $0.00^{\mathrm{m}}$ & $3.75^{\mathrm{ijklm}}$ & $4.75^{\mathrm{ijkl}}$ & 2.83 & 2.13 \\
\hline & Red.\% & 100 & 100 & 78.54 & 73.22 & 83.92 & 87.94 \\
\hline \multirow[t]{2}{*}{ Sylgard 309} & $13^{\text {abcde }}$ & $6^{\text {hijk }}$ & $9.5^{\mathrm{efgh}}$ & $12.25^{\text {bcde }}$ & $15.75^{\mathrm{abc}}$ & 12.5 & 10.88 \\
\hline & Red.\% & 56.67 & 37.75 & 35.30 & 18 & 30.35 & 36.93 \\
\hline \multirow[t]{2}{*}{ Tween 80} & $13.5^{\text {abcde }}$ & $7.25^{\text {fghi }}$ & $10.75^{\text {defg }}$ & $14.5^{\mathrm{abcd}}$ & $16.25^{\mathrm{ab}}$ & 13.83 & 12.19 \\
\hline & Red.\% & 49.58 & 32.17 & 26.26 & 18.57 & 25.67 & 31.65 \\
\hline \multirow[t]{2}{*}{ Lambda-cyhalothrin+sylgard 309} & $12.75^{\text {abcde }}$ & $0.00^{\mathrm{m}}$ & $0.00^{\mathrm{m}}$ & $1^{\operatorname{lm}}$ & $2^{\mathrm{klm}}$ & 1 & 0.75 \\
\hline & Red.\% & 100 & 100 & 94.62 & 89.39 & 94.67 & 96 \\
\hline \multirow[t]{2}{*}{ Lambda-cyhalothrin+tween 80} & $13.75^{\text {abcde }}$ & $0.00^{\mathrm{m}}$ & $0.00^{\mathrm{m}}$ & $1.5^{\operatorname{lm}}$ & $2.25^{\mathrm{jklm}}$ & 1.25 & 0.94 \\
\hline & Red.\% & 100 & 100 & 92.51 & 88.93 & 93.81 & 95.36 \\
\hline \multirow[t]{2}{*}{ Malathion+sylgard 309} & $15.75^{\mathrm{abc}}$ & $0.00^{\mathrm{m}}$ & $1^{\operatorname{lm}}$ & $4^{\mathrm{ijklm}}$ & $4.75^{\mathrm{ijkl}}$ & 3.25 & 2.44 \\
\hline & Red.\% & 100 & 94.59 & 82.56 & 79.59 & 85.58 & 89.19 \\
\hline \multirow[t]{2}{*}{ Malathion+tween 80} & $13^{\text {abcde }}$ & $0.00^{\mathrm{m}}$ & $1.25^{\operatorname{lm}}$ & $4.5^{\mathrm{ijklm}}$ & $5^{\mathrm{ijkl}}$ & 3.58 & 2.69 \\
\hline & Red.\% & 100 & 91.81 & 76.23 & 73.98 & 80.67 & 85.51 \\
\hline \multirow[t]{2}{*}{ Thiamethoxam +sylgard 309} & $14.5^{\text {abcd }}$ & $0.00^{\mathrm{m}}$ & $0.00^{\mathrm{m}}$ & $3.25^{\mathrm{ijklm}}$ & $4^{\mathrm{ijklm}}$ & 2.42 & 1.81 \\
\hline & Red.\% & 100 & 100 & 84.61 & 81.34 & 88.65 & 91.49 \\
\hline \multirow[t]{2}{*}{ Thiamethoxam +tween 80} & $13.75^{\text {abcde }}$ & $0.00^{\mathrm{m}}$ & $0.00^{\mathrm{m}}$ & $3.5^{\mathrm{ijklm}}$ & $4.25^{\mathrm{ijklm}}$ & 2.58 & 1.94 \\
\hline & Red.\% & 100 & 100 & 82.52 & 79 & 87.17 & 90.38 \\
\hline Control & $11.5^{\text {cdef }}$ & $12.25^{\mathrm{bcde}}$ & $13.5^{\mathrm{abcde}}$ & $16.75^{\mathrm{a}}$ & $17^{\mathrm{a}}$ & 15.75 & 14.88 \\
\hline
\end{tabular}

$\mathrm{LSD} \leq 0.05$ level for interactions between $(\mathrm{TxP})=5.863$ 
Elalfy, et al.

Table 5. Efficiency of the tested insecticides, two adjuvants and their mixtures against the onion thrips, Thrips tabaci attacking wheat plants in the field 2017 season

\begin{tabular}{|c|c|c|c|c|c|c|c|}
\hline \multirow[t]{2}{*}{ Treatment } & \multirow[t]{2}{*}{$\begin{array}{c}\text { Count } \\
\text { before } \\
\text { spraying }\end{array}$} & \multirow[t]{2}{*}{$\begin{array}{l}\text { Initial } \\
\text { effect }\end{array}$} & \multicolumn{3}{|c|}{$\begin{array}{l}\text { Number of individuals and } \\
\text { reduction percentage after } \\
\text { different days from application }\end{array}$} & \multirow[t]{2}{*}{$\begin{array}{l}\text { Mean of } \\
\text { residual } \\
\text { effect }\end{array}$} & \multirow[t]{2}{*}{$\begin{array}{l}\text { General } \\
\text { average }\end{array}$} \\
\hline & & & 3 & 7 & 10 & & \\
\hline \multirow[t]{2}{*}{ Lambda-cyhalothrin } & $13.5^{\text {bcd }}$ & $0.00^{\mathrm{q}}$ & $0.00^{\mathrm{q}}$ & $1^{\mathrm{opq}}$ & $2^{\mathrm{mnop}}$ & 1 & 0.75 \\
\hline & Red.\% & 100 & 100 & 94.37 & 90.20 & 94.86 & 96.14 \\
\hline \multirow[t]{2}{*}{ Malathion } & $11.5^{\mathrm{ef}}$ & $0.00^{\mathrm{q}}$ & $1.75^{\text {nopq }}$ & $4.25^{\mathrm{ijkl}}$ & $5.5^{\mathrm{ij}}$ & 3.83 & 2.88 \\
\hline & Red.\% & 100 & 87.27 & 71.94 & 68.37 & 75.86 & 81.89 \\
\hline \multirow[t]{2}{*}{ Thiamethoxam } & $10^{\mathrm{f}}$ & $0.00^{\mathrm{q}}$ & $1^{\mathrm{opq}}$ & $1.5^{\mathrm{opq}}$ & 2. $5^{\operatorname{lmno}}$ & 1.67 & 1.25 \\
\hline & Red.\% & 100 & 91.63 & 88.61 & 83.47 & 87.90 & 90.93 \\
\hline \multirow[t]{2}{*}{ Sylgard 309} & $10.75^{\mathrm{ef}}$ & $5.25^{\mathrm{ijk}}$ & $7.5^{\mathrm{gh}}$ & $10.25^{\mathrm{f}}$ & $13.75^{\mathrm{ab}}$ & 10.5 & 9.19 \\
\hline & Red.\% & 53.43 & 41.62 & 27.60 & 15.42 & 28.21 & 34.52 \\
\hline \multirow[t]{2}{*}{ Tween 80} & $10^{\mathrm{f}}$ & $5.75^{\mathrm{hi}}$ & $8^{g}$ & $10.75^{\mathrm{ef}}$ & $14.25^{\mathrm{ab}}$ & 11 & 9.69 \\
\hline & Red.\% & 45.17 & 33 & 18.38 & 5.77 & 19.05 & 25.58 \\
\hline \multirow[t]{2}{*}{ Lambda-cyhalothrin+sylgard 309} & $11.75^{\mathrm{def}}$ & $0.00^{\mathrm{q}}$ & $0.00^{\mathrm{q}}$ & $0.5^{\mathrm{pq}}$ & $1.25^{\mathrm{opq}}$ & 0.58 & 0.44 \\
\hline & Red.\% & 100 & 100 & 96.77 & 92.96 & 96.58 & 97.43 \\
\hline \multirow[t]{2}{*}{ Lambda-cyhalothrin+tween 80} & $14^{\text {abc }}$ & $0.00^{\mathrm{q}}$ & $0.00^{\mathrm{q}}$ & $0.75^{\mathrm{opq}}$ & $1.75^{\text {nopq }}$ & 0.83 & 0.63 \\
\hline & Red.\% & 100 & 100 & 95.93 & 91.73 & 95.89 & 96.92 \\
\hline \multirow[t]{2}{*}{ Malathion+sylgard 309} & $10.75^{\text {ef }}$ & $0.00^{\mathrm{q}}$ & $1.25^{\mathrm{opq}}$ & $3.5^{\mathrm{klmn}}$ & $4.75^{\mathrm{ijk}}$ & 3.17 & 2.38 \\
\hline & Red.\% & 100 & 90.27 & 75.28 & 70.78 & 78.78 & 84 \\
\hline \multirow[t]{2}{*}{ Malathion+tween 80} & $11.25^{\text {ef }}$ & $0.00^{\mathrm{q}}$ & $1.5^{\mathrm{opq}}$ & $3.75^{\mathrm{jklm}}$ & $5.25^{\mathrm{jik}}$ & 3.5 & 2.63 \\
\hline & Red.\% & 100 & 88.84 & 74.69 & 69.14 & 77.56 & 83.17 \\
\hline \multirow[t]{2}{*}{ Thiamethoxam +sylgard 309} & $10.5^{\mathrm{ef}}$ & $0.00^{\mathrm{q}}$ & $0.00^{\mathrm{q}}$ & $1^{\mathrm{opq}}$ & $2^{\mathrm{mnop}}$ & 1 & 0.75 \\
\hline & Red.\% & 100 & 100 & 92.77 & 87.40 & 93.39 & 95 \\
\hline \multirow[t]{2}{*}{ Thiamethoxam +tween 80} & $11^{\mathrm{ef}}$ & $0.00^{\mathrm{q}}$ & $0.00^{\mathrm{q}}$ & $1.25^{\mathrm{opq}}$ & $2.25^{\mathrm{mnop}}$ & 1.17 & 0.88 \\
\hline & Red.\% & 100 & 100 & 91.37 & 86.47 & 92.61 & 94.46 \\
\hline Control & $10.25^{\mathrm{f}}$ & $10.75^{\mathrm{ef}}$ & $12.25^{\text {cde }}$ & $13.5^{\mathrm{bcd}}$ & $15.5^{\mathrm{oa}}$ & 13.75 & 13 \\
\hline
\end{tabular}

LSD $\leq 0.05$ level for treatments $=0.7560$ LSD $\leq 0.05$ level for periods $=0.5318$

$\mathrm{LSD} \leq 0.05$ level for interactions between $(\mathrm{TxP})=1.8129$ 


\section{Zagazig J. Agric. Res., Vol. 46 No. (6A) 2019}

\section{REFERENCES}

Abd-Ella, A.A. (2015). Effect of several insecticides on pomegranate aphid, Aphis punicae (Passerini) (Homoptera: Aphididae) and its predators under field conditions. J. Comp., 45 (1): 90-98.

Bereś, P. K., H. Kucharczyk and D. Górski (2016). Effects of insecticides used against the european corn borer on thrips abundance on maize. Plant Protect. Sci., 53 (1): 44-49.

Blackman, R. L. and V.F. Eastop (2000). Aphids on the World's Crops. An Identification and Information Guide Chichester, UK: John Wiley and Sons. $2^{\text {nd }} E d ., 375$.

Dewar, A.M. and N. Carter (1984). Decision trees to assess the risk of cereal aphid outbreaks in summer in England. B. Entomol. Res., 74:387-398.

Duraimurugan, P. and A. Jagadish (2011). Preliminary studies on the biology of Scirtothrips dorsalis Hood (Thysanoptera: Thripidae) as a pest of rose in India. Arch. Phytopathol. Plant Prot., 44:37-45.

Ding, J., H. Li, Z. Zhang, J. Lin, F. Liu and W. Mu (2018). Thiamethoxam, clothianidin, and imidacloprid seed treatments effectively control thrips on corn under field conditions. J. Insect Sci., 18 (6): 1-8.

El-Hariry, M.A. (1979). Biological and ecological studies on aphids attacking corn and wheat in Egypt. M.Sc. Thesis, Fac. Agric., Ain Shams Univ., Egypt.

El-Heneidy, A.H. (1994). Efficacy of aphidophagous insects against aphids at wheat fields in Egypt, a 5-year evaluation. Egypt. J. Biol. Pest Control, 4 (2): 113-123.

El-Naggar, J. B. and N. A. Zidan (2013). Field evaluation of imidacloprid and thiamethoxam against sucking insects and their side effects on soil founa. J. Plant Prot. Res., 53 : 4.

Gaafar, N. (2010). Wheat midges and thrips information system: Monitoring and decision making in central Germany. PhD Diss Martin- Luther- Uni Halle, 109 pages.

Gaber, A.S., A.A. Abd-Ella, G.H. AbouElhagag and Y.A. Abdel-Rahman (2015).
Field efficiency and selectivity effects of selected insecticides on cotton aphid, Aphis gossypii Glover (Homoptera: Aphididea) and its predators. J. Phytopathol. and Pest Manag., 2 (1): 22-35.

Girma, M.G., E. Wilde and T. Harvey (1993). Russian wheat aphids (Homoptera: Aphidsidae) affects yield and quality of wheat. J. Econ. Entomol., 86: 594-601.

Hatchett, A. H., K .J. Starks and J. A. Webster (1987). Insect and Mites pest of wheat, 625668. In: Wheat and Wheat Improvement (ed. EG. Heyne). Agronomy Monog.13, $2^{\text {nd }}$ Ed., ASA-CSSA, Madison, Wisconsin, USA,765.

Henderson, C.F. and E.W. Tilton (1955). Test with acaracides against the brown wheat mite. J. Econ. Entomol., 48: 157-161.

Kieckhefer, R. and J. Gellner (1992). Yield losses in winter wheat caused by low-density cereal aphids populations. Agron. J., 84: 180183.

Lowe, H. J. B. (1987). Breeding for resistance to insect. Wheat breeding (ed. FGH Lupton). Chapman and Hall Ltd. UK., 423-454.

Mound, L. A. (2005) Thysanoptera: Diversity and Interactions. Ann. Rev. Entomol., 50:247-269.

Moritz, G. (2006) Die Thripse.Die Neue BrehmBücherei Bd., 663: 384.

Naeem, M., Q. Zeb, S.A. Khan and S. Ahmad (2016). Effect of insecticides on the population of aphids, natural enemies and yield components of wheat. Pak. J. Zool., 48: 1839-1848.

Newsom, L. (1980). General accomplishments toward better pest control in soybean. New Technol. Pest Contr., $9: 51$.

Parrella, M.P. and T. Lewis (1997) Integrated Pest Management in Field Crops. Thrips as crop Pests Lewis T. (ed.) CAB International, Wallingford, UK, 595-614.

Sadozai, A., Q. Zeb, T. Iqbal, S. Anwar, H. Badshah, A. Ali, M. Ahmed and M. Tahir (2009). Testing the efficacy of different insecticides against onion thrips in Tarnab, Peshawar. J. Agric., 25: 2. 


\section{Elalfy, et al.}

Steffey, K.M.G. (2012) Managing Insect Pests. Illinois Agron. Handbook, 179-196.

Trdan, S. and L. Milevoj (1999). The cereal aphids (Sitobion avenae F.) wheat pest. Sodobno kmetijstvo (Slovenia), 32:119-128.

Ul Ane, N., M. Hussain, T. Zainab and S. Fatima (2016). Effect of lambda cyhalothrin and imidacloprid on the population density of aphid attacking strawberry. Int. J. Fauna and Biol. Studies, 3 (1): 121-123.

Volkmar, C., A. Schröder, N. Gaafar, H. Cöster and J. Spilke (2009). Evaluierungsstudie zur Befallssituation von Thripsen in einem Winterweizensortiment. Mitt. Deut. Ges. Allg. and Angew. Entomol., 17:227-230.

\section{فعالية بعض المبيلات الحشرية والمواد المساعدة ومخاليطها لمكافحة حشرة مَنْ القمح وحشرة التربس على نباتات القمح

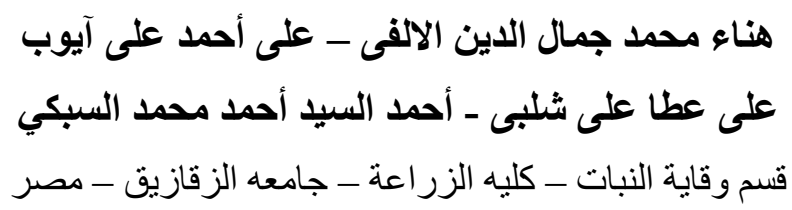

أجريت تجارب حقلية لتقييم تأثير ثلاثة مبيدات حشرية منفردة أو فى مخاليط مع مادتين مساعدتين (توين • ـ وسيلجارد

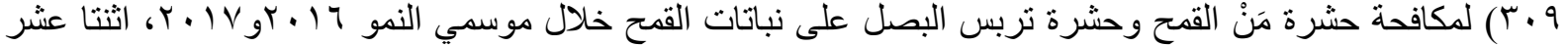

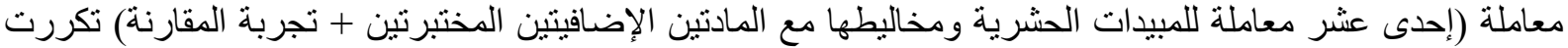

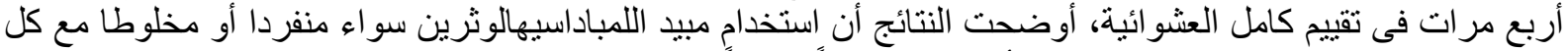

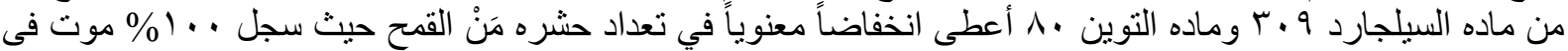

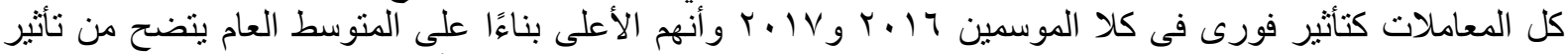

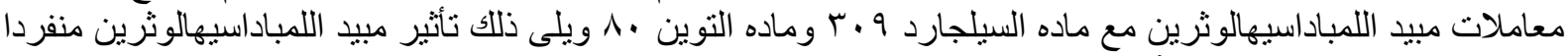

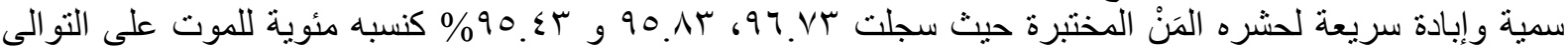

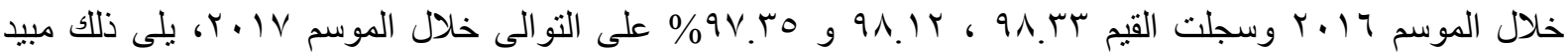

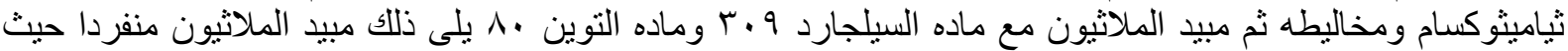

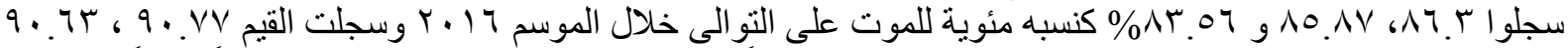

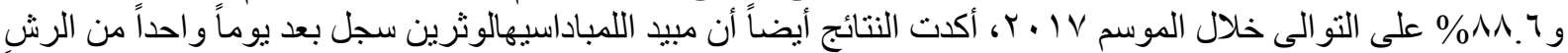

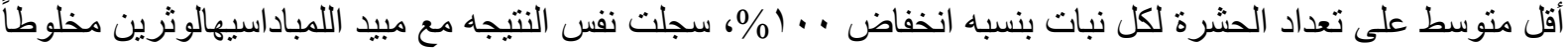

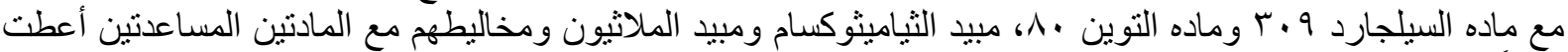

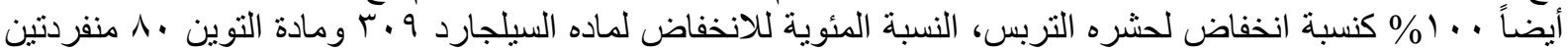

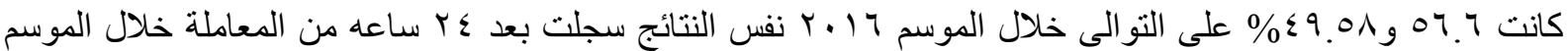

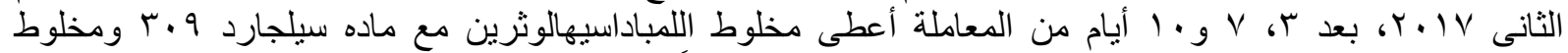

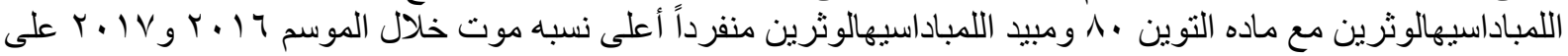

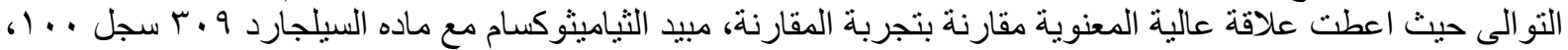

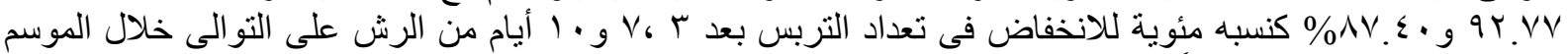

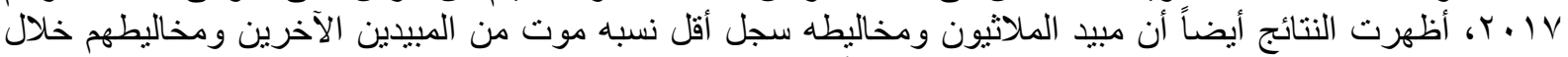

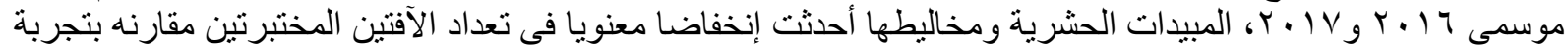

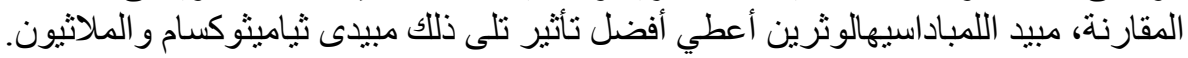

رئيس بحوث متفرغ - معهد بحوث وقاية النباتات ـ مركز البحوث الزر اعية. أستاذ المبيدات المتفرغ غ - كلية الزر اعة - جامعة الزقازيق. 